\title{
INFLUENCE OF NATIONAL MENTALITY ON THE COMPETITIVENESS OF TOURISM DESTINATIONS: A CASE STUDY OF AZERBAIJAN AND GEORGIA
}

\author{
Larisa Korganashvili', \\ Natavan Mammadova ${ }^{2}$
}

${ }^{1}$ Ivane Javakhishvili Tbilisi State University, Tbilisi, Georgia

${ }^{2}$ Baku Business University, Baku, Azerbaijan
Correspondence:

Larisa Korganashvili

e-mail:

I.korganashvili@yahoo.com

\begin{abstract}
:
Despite strengthening of the globalisation process, our national factor is the utmost difficult problem, on the basis of which inter-ethnic relations are exacerbated, dangerous places are created and terrorist acts are provoked. National problems and inter-ethnic conflicts have a negative impact on tourism development. In connection with this understanding of the mentality of own people and intercultural relations, "tourist-local population" and prevention of ethnic conflicts is an urgent problem.

The aim of this study is to examine and identify the importance of national mentality in improving the international competitiveness of tourism destinations on the examples of Georgia and Azerbaijan, as countries with areas of inter-ethnic conflicts. The paper analyses the competitiveness of Azerbaijan and Georgia as tourism destinations and shows the mentality of value in tourism development and enhanced competitiveness of tourism destinations.
\end{abstract}

Keywords:

tourism, destination, mentality, competitiveness, Azerbaijan, Georgia.

\section{INTRODUCTION}

In recent years, tourism has become a global socio-economic phenomenon, which has a significant impact on the world economy and development of many countries, as a factor improving the quality of life of the inhabitants of the planet as a whole and individual countries - in particular. According to the World Travel \& Tourism Council (WTTC), the Travel \& Tourism (T\&T) sector is expected to continue growing at $4 \%$ annually, more rapidly than financial services, transport and manufacturing. The direct contribution of travel \& tourism to the world's GDP was USD 2,229.8 bn (3.0\% of total GDP) in 2015, and the total contribution - USD 7,170.3 bn (9.8\% of GDP). Travel \& Tourism directly supported $107,833,000$ jobs (3.6\% of total employment) and the total contribution was $9.5 \%$ of total employment $(283,578,000$ jobs). Visitor exports generated USD 1,383.8 bn (5.7\% of total exports. Travel \& Tourism investment was USD 814.4 bn, or $4.3 \%$ of total investment (WTTC, 2016). According to the UNWTO World Tourism Barometer, international tourist arrivals rose by $4.4 \%$ in 2015 to reach a total of 1,184 million in 2015. Some 50 million or more tourists (overnight visitors) travelled to international destinations around the world last year compared to 2014. 2015 marks 
the 6th consecutive year of above-average growth, with international arrivals increasing by $4 \%$ or more every year since the post-crisis year of 2010 (UNWTO, 2016).

Tourism market has become global, as a result new opportunities for development of international tourism, for diversification of the tourism product, increasing the awareness about the possibilities of tourist choice among tourism products, for the expansion of opportunities of free movement around the world. International tourism contributes to the formation of a new type of spatial relations and cultural enrichment of countries and nations.

As regards the importance of tourism in the global economy, there imposes a question related to the role of Azerbaijan and Georgia in the global tourism market. In recent years, tourism in Azerbaijan and Georgia has had a momentum of development, but both countries are faced with fierce competition in the global tourism market. Therefore, the agenda is the issue of increasing the global competitiveness of Azerbaijan and Georgia, as tourism destinations.

Tourism destination competitiveness is affected by numerous factors, including the national mentality. The national factor is the great challenge of our time, interethnic relations are exacerbated from it, hotbeds of danger are created and terrorist acts are provoked. All this has a negative impact on tourism development. Understanding the national peculiarities of mentality and intercultural relations "tourist-local population," the prevention of ethnic conflict is an urgent problem. In this regard, the aim of this study is to examine and identify the importance of national mentality in improving the international competitiveness of tourism destinations on the examples of Azerbaijan and Georgia, as countries with the territory of interethnic conflicts.

\section{RESULTS AND DISCUSSION}

The post-Soviet development of Azerbaijan and Georgia is related to the transition from a command economy to a market system, which is characterized by a high degree of openness. In the context of globalization and open economy, sustainable economic growth of the country and its success in the world markets depends on the international competitiveness of the national economy. The World Economic Forum defines competitiveness as a set of institutions, policies, and factors that determine the level of productivity of an economy, which in turn sets the level of prosperity that the country can reach (WEF, 2016, p. 4). Along with the study of issues of global competitiveness of countries, WEF defines the travel \& tourism competitiveness.
The development of tourism is directly linked to destination competitiveness. The issue of competitiveness of tourism destinations has been explored by many researchers. As a result of the systematization of their work, the following are the main research areas of tourism destination competitiveness.

Research on the basis of geographical approaches. In this regard, the following works should be noted: The United States (Ahmed \& Krohn), Sun/Lost City, South Africa (Botha, Crompton \& Kim), Las Vegas (Chon \& Mayer), Australia (Dwyer, Livaic \& Mellor), South Korea and Australia (Kim, Choi, Moore, Dwyer, Faulkner, Mellor \& Livaic), and others.

On the basis of different methodological approaches, one should note the following aspects: destination positioning (Chacko), destination management systems (Baker, Hayzelden \& Sussmann), price competitiveness (Dwyer, Forsyth, Rao, Stevens), quality management (Go \& Govers), nature-based tourism (Huybers \& Bennett), strategic management (Jamal \& Getz; Soteriou \& Roberts), and others. The methods of the World Economic Forum are among the most common methodological approaches to competitiveness assessment.

The studies based on the conceptual models. Namely, based on the conceptual models, the model proposed by Crouch and Ritchie should be noted (Crouch \& Ritchie, 1993, 2000, 2003; Crouch, 2007). Their aim has been to develop a conceptual model based on the theories of comparative advantage (Smith, 1776; Ricardo, 1817) and competitive advantage (Porter, 1990). Model Crouch and Ritchie was the main theoretical basis for the research on tourism destinations. The literature has widely explored the concept of cluster area competitiveness (destination), which links the competitiveness of the territory (destination) with the presence of a cluster of related industries. The basis of this concept is derived from the system of the international competitiveness of the determinant of Porter (1990, pp. 74-75). The starting point is that the tourism destination competitiveness represents "ability of the place to optimize its attractiveness for residents and non-residents, to deliver quality, innovative, and attractive tourism services to consumers and to gain market shares on the domestic and global market places, while ensuring that the available resources supporting tourism are used efficiently and in a sustainable way" (Dupeyras \& MacCallum, 2013, p. 14).

Tourism is a complex geospatial and socio-economic system, so the analysis of the trends of its development and improvement should be primarily based on a systematic approach. Tourism as a system was considered 
by N. Leiper, Prof. of Meissen University (Auckland, New Zealand) (Leiper, 2004). Leiper (2004) views tourism as an open system encompassing five interelated segments: one human element (tourists), three geographic elements (traveler-generating region, tourism destination region, and transit route), and one industrial element (tourist industries). Political, economic and technological environments represent the external forces. This model was initiated by Leiper in 1979. The label "whole tourism systems" was adapted when Getz (1986) coined the term "whole system models" (p. 25) of tourism in his review of tourism models. The most recent version of the tourism systems model is disclosed in Leiper (2004). Leiper's (1979) tourism systems model was suggested to mitigate tourism research fragmentation, an issue he considered to be the result of its multidisciplinary nature. The elements of the original model put forward in 1979 are almost the same as this most recent version (Leiper, 2004), with the exception of the original industrial element, the tourist "industry," which Leiper (2004) now refers to as "tourist industries" (Lamont, 2009).

A tourist as the central point in the N. Leyper's model, who wishes to carry out a travel, triggers the entire tourism system (Gerasimenko, 2013). It is this desire that creates the demand for tourism services in the region. In turn, this desire should arise because of the attractive tourism destination in the region.

Almost all countries in the world are offering their services in the global tourism market. Each of them has its own specific way and contributes to the diversity of tourist motivations, to differentiation of supply and demand, the formation of various market segments and niches. In this regard, tourism market in Azerbaijan and Georgia is developing despite fierce competition.

According to the ranking of WEF GCI for the period 2015-2016, Azerbaijan occupies the $40^{\text {th }}$ place among 140 countries and is 26 positions ahead of Georgia, though, compared with a rating of 2015-2016, it has deteriorated its position for 2 levels, and it then assumed the $38^{\text {th }}$ place among 148 countries (Figure 1). Despite the fact that GCI of Azerbaijan is ahead of Georgia, on the WEF T \& TCI in 2015, it is 13 positions behind Georgia. In the ranking of 2008, this difference was 7 positions in 2009 - 3, in 2011 - 10 and in 2013 - 12 (Figure 2). The higher position of Georgia can be attributed to the fact that tourism is a priority for its economy. According to prioritization of travel \& tourism, Georgia occupies $53^{\text {rd }}$ place, Azerbaijan $-58^{\text {th }}$ (WEF, 2016, pp. 85, 155). In 2014, in the structure of Azerbaijan's
GDP, the main place was occupied by Industry - 58.3\%, Services accounted for $36.0 \%$, and Agriculture - 5.7\%. For Georgia, these figures are 24.4, 66.4 and 9.2\%, respectively [World Bank]. The share of travel services of Azerbaijan exports is $57.0 \%$, imports $-29.5 \%$, and for Georgia 60.5 and $19.0 \%$, respectively (WTO).

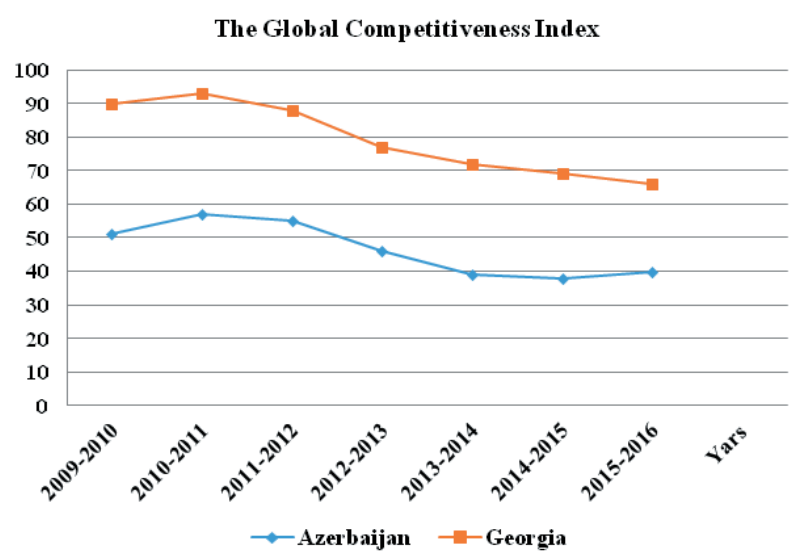

Figure 1. Ranking of GCI of Azerbaijan and Georgia

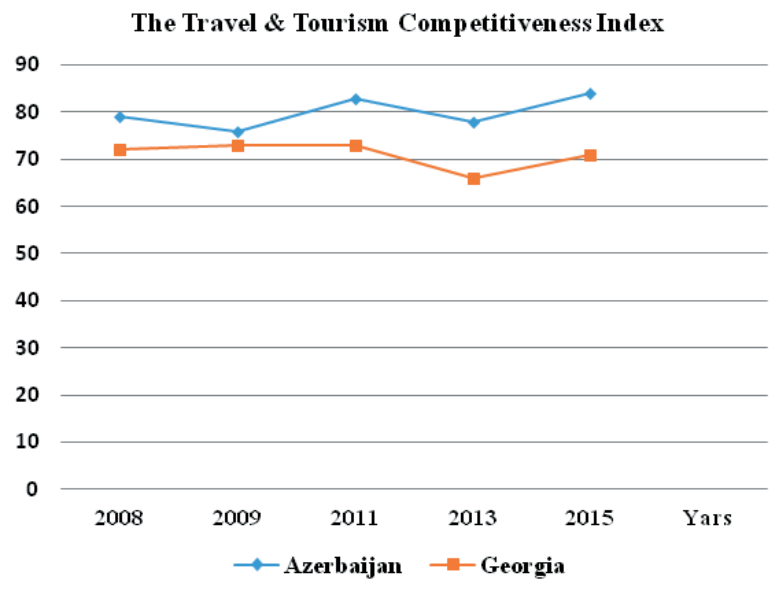

Figure 2. Ranking of T\&TCI of Azerbaijan and Georgia

Fig. 3 shows the components of T \& TCI of Azerbaijan and Georgia. The highest score points in Azerbaijan are on the Health and Hygiene - 5.96, Safety and Security - 5.83, Price Competitiveness - 4.78; Georgia - on Health and Hygiene - 6.12, Safety and Security - 5.96, and Business Environment - 4.91. Like Azerbaijan, Georgia has the lowest scores for Cultural Resources and Business Travel (1.53 and 1.45, respectively) and Natural Resources (2.03 and 2.07, respectively) (Figure 3). 


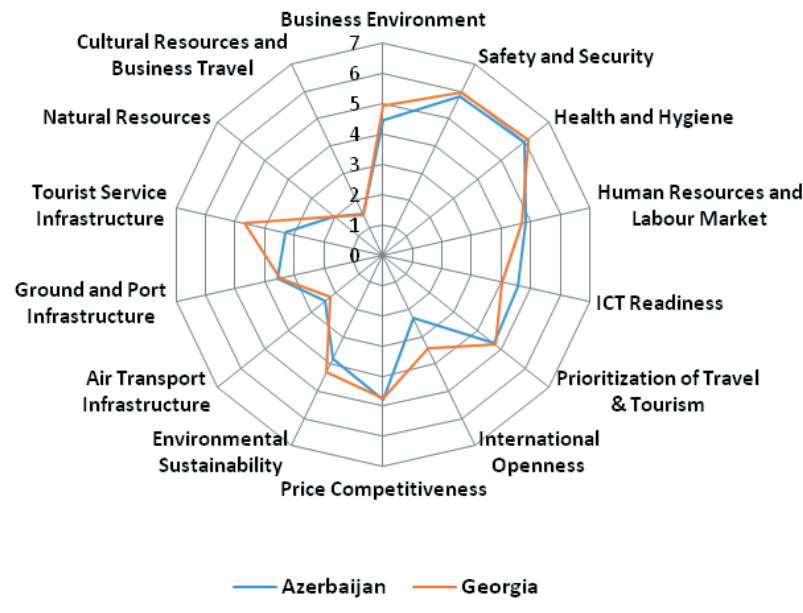

Figure 3. Composition of T\&TCI of Azerbaijan and Georgia

According to the World Travel and Tourism Council in 2015, the direct contribution of travel and tourism in Georgia's GDP amounted to GEL2, 195.9mn (7.1\% of total GDP), and total contributions - GEL7, $310.2 \mathrm{mn}$ (23.5\% of GDP). This industry directly employs 347,000 people ( $20.1 \%$ of total employment), and with the related industries $-347,000$ people $(20.1 \%$ of total employment) (WTTC, 2016). Accordingly, tourism is increasingly becoming a factor of multiplier effect on the economy and social sphere of the country. Visitor exports accounted for $36.4 \%$ of total exports, and Investment $-3.4 \%$ of total investment. The indicators for Azerbaijan were much lower: the direct contribution of travel and tourism accounted for $2.8 \%$ of total GDP, total contribution $-10.5 \%$, those directly employed in the tourism sector with $2.6 \%$ of total employment, total contribution $-9.5 \%$ of total employment. Visitor exports accounted for $13.7 \%$ of total exports, and Investment $-2.9 \%$ of total investment (Table 1 ).

The tourism sector is the specific area of activity, characterized by economic and social aspects influencing the formation of a competitive tourism product. The provision of tourism services is carried out in a particular tourism destination, where the tourist has contacts with the local population. In this regard, it is important for tourists to have a friendly attitude towards the local population. The relationship between "tourist-locals" is a difficult problem, without which it is impossible to develop tourism and increase competitiveness of a tourism product and most destinations.

Everyday coexistence of foreign tourists and the local population - representatives of different cultures requires understanding the essence of the national mentality, the search for new approaches to its assessment, understanding its positive and negative aspects, identifying opportunities for mentality changes within the frame of the progressive forces of the society. National mentality is a socio-psychological state of the ethnic community (nation, nationality), which is based on the current society's existing knowledge, beliefs, values, and other social traits, and reflects the results of long-term and sustainable impact of the natural geographic and socioeconomic conditions of formation and development of this community. Each ethnic group, state, nation has specific historical and economic developmental path, own culture, own behavior. Understanding the ethnic characteristics of the people, respect for the culture and

Table 1. Contribution of travel and tourism to the economies of Azerbaijan and Georgia

\begin{tabular}{lll}
\hline & \multicolumn{1}{c}{ Azerbaijan } & \multicolumn{1}{c}{ Georgia } \\
\hline $\begin{array}{l}\text { GDP: direct } \\
\text { contribution }\end{array}$ & AZN1,521.3mn (2.8\% of total GDP) & GEL2,195.9mn (7.1\% of total GDP) \\
\hline GDP: total contribution & AZN5,586.8mn (10.5\% of GDP) & GEL7,310.2mn (23.5\% of GDP) \\
\hline $\begin{array}{l}\text { Employment: direct } \\
\text { contribution }\end{array}$ & $\begin{array}{l}118,500 \text { jobs (2.6\% of total employ- } \\
\text { ment })\end{array}$ & $\begin{array}{l}100,500 \text { jobs (5.8\% of total employ- } \\
\text { ment) }\end{array}$ \\
\hline $\begin{array}{l}\text { Employment: total } \\
\text { contribution }\end{array}$ & $\begin{array}{l}438,000 \text { jobs }(9.5 \% \text { of total employ- } \\
\text { ment })\end{array}$ & $\begin{array}{l}347,000 \text { jobs (20.1\% of total employ- } \\
\text { ment })\end{array}$ \\
\hline $\begin{array}{l}\text { Visitor exports } \\
\text { Investment }\end{array}$ & AZN2,678.4mn (13.7\% of total exports) & GEL4,701.0mn (36.4\% of total exports) \\
\hline
\end{tabular}

Source: WTTC, Azerbaijan (2016), ${ }^{* * W T T C, ~ G e o r g i a ~(2016) ~}$ 
values of other people, helps to overcome ethnic barriers and conflicts. Ethnic conflict is an undesirable phenomenon in life of any society as it plays the role of a brake in its development, creates social instability and causes serious damage to the country's economy and reduces its competitiveness. The people of Azerbaijan and Georgia have experienced negative effects of international conflicts (Karabakh, Georgian-Abkhazian and Georgian-Ossetian conflicts), which are expressed not only as human victims, but are complicated by large flows of refugees, destruction of material and cultural values etc. The presence of conflict areas creates serious problems for tourism development, hinders the full satisfaction of tourist needs and reduces the overall image of the country in the eyes of the world community.

The transformation processes taking place in Azerbaijan and Georgia contributed to the growth of national consciousness, increased the attention to the preservation and development of national cultures, revival of popular traditions and religious beliefs. As a result, this provides a fertile ground for the emergence of new international conflicts, which in order to prevent particular attention should be paid to the education of tolerance to representatives of other nations. Particular emphasis is placed on such characteristic feature of the Azerbaijani and Georgian people, as the national tolerance.

The essence of the Azerbaijani and Georgian national mentality is multifaceted. As Azerbaijanis and Georgians are characterized by open heart, hospitality, maximalist and extreme, the pursuit of absolute values, love of freedom and at the same time, willingness to borrow cultural values (both positive and negative) of Western civilization.

Christianity represents the foundation for the formation of the Georgian mentality, triggered by Western civilization and imposed on the spirit of the East. As a result, it formed a special mentality, the properties of which can be called a paradox, perception of the world "this and that," in sharp contrast with the Western mentality, which is characterized by an approach from a position of "either-or". This property of the Georgian mentality shows the features of economic behavior of the population and it is an important factor in the process of entrepreneurship. In turn, the Azerbaijani mentality is based on Islam, but despite that it has many similar characteristics to the Georgian mentality. The residents of Azerbaijan and Georgia are characterized by the depth of the inner life, entrustment of partial personal liberty to the team, a high degree of non-economic components of entrepreneurial success. According to the Georgian mentality, ownership and hoard- ing are more negative than positive traits. However, the Azerbaijani mentality is characterized by a desire for hoarding. In addition, the success in the Azerbaijani and Georgian culture is not the result of objective processes, nor the result of their own efforts, but rather the result of personal connections or "God given". At the same time, freedom is understood as the ability to do what you want. For the majority of the population, there is a deep relationship in the chain concepts of "freedom - independence - responsibility". Based on this, until recent days, violation of law has been common and therefore - the society was criminalized.

Nowadays, the elements of Western market economic thinking exert a considerable bearing on the people's conduct (especially the younger generation): a sense of ownership, personal economic independence, initiative, pragmatism, flexibility, adaptability, willingness to act in a competitive environment. Nonetheless, the economic conduct of an individual in Azerbaijan and Georgia differs from the economic conduct of Western man. Rationalism of economic conduct in the Western European variant is equal to the desire for gain and it arises from the continuous comparison of earnings and expenses that seem to be normal conduct. In Azerbaijan and Georgia, in view of the Soviet past, social and historical features of rationalism could not be found in the Western European version. Economic conduct is frequently irrational and economic benefits are sometimes overlooked due to the effects of subjective perception of others and engagement in the collective spirit. This distinctive feature of the inhabitants of Azerbaijan and Georgia introduces uncertainties in the situation, coupled with the economic choice. In other words, economic conduct of individuals from Azerbaijan and Georgia should be observed in a more rational manner since the features of the Azerbaijan and Georgian mentality and economic thinking are the foundation of economic conduct. Accordingly, when we consider the mentality of the population of Azerbaijan and Georgia, it is of vital importance to start from the position to alter the paradigm of rationality and introduction of subjectivity, which suggests that the individual himself chooses between alternatives, with an emphasis on own assessment of benefits and expenses.

Considerable attention needs to be devoted to this characteristic of the mentality of the Azerbaijani and Georgian people, as a special commitment to education and accumulation of new knowledge. It is this feature that creates the foundation for improving the competitiveness of not only the travel and tourism industry, but also the global competitiveness of Azerbaijan and Georgia. 
The study of the influence of mentality on tourism destination competitiveness reveals a new perspective on this topic. The problem presented herein has prospects for further deepening. In particular, research is ongoing and will be able to increase its validity through a more detailed examination of the specifics of the Azerbaijani and Georgian national mentality and its impact on improving the competitiveness of Azerbaijan and Georgia, as tourism destinations.

\section{CONCLUSION}

In recent years, the influence of the national mentality on the economic development of the country has increased. Accounting for the factors of the national mentality is particularly important in a tourism destination, as there are conflicting interests of different cultures - foreign tourists and the local population. Tourists wanting to get maximum satisfaction from their travels may become catalysts for inter-ethnic conflicts. In turn, the centers of inter-ethnic conflicts reduce the competitiveness of tourism destinations and the overall image of the country.

Azerbaijan and Georgia are the countries with interethnic conflicts (Karabakh, Georgian-Abkhazian and Georgian-Ossetian) lasting for many years, despite the fact that the people of these countries are characterized by national tolerance, an open heart and hospitality. Accordingly, the mentality of the Azerbaijani and Georgian people may become one of the conditions to prevent the escalation of ethnic conflicts and increase the competitiveness of Azerbaijan and Georgia as tourism destinations.

\section{REFERENCES}

Crouch, G.I. (2007). Modelling destination competitiveness: a survey and analysis of the impact of competitiveness attributes. Retrieved April 6, 2016 from http://www.sustainabletourismonline.com/awms/ Upload/Resource/bookshop/Crouch_modelDestnComp-web.pdf

Dupeyras, A., \& MacCallum, N. (2013). Indicators for Measuring Competitiveness in Tourism: A Guidance Document. OECD Tourism Papers, 2013/02. doi:10.1787/5k47t9q2t923-en

Gerasimenko, V.G. (2013). Theory of system approach to the research. Retrieved April 6, 2016 from http:// dspace.oneu.edu.ua/jspui/handle/123456789/553

Getz, D. (1986). Models in tourism planning: Towards integration of theory and practice. Tourism Management, 7(1), 21-32.
Lamont, M.J. (2009). Independent bicycle tourism: a whole tourism systems perspective. Tourism Analysis, 14(5), 605-620. doi:10.3727/108354209X12597959359176

Leiper, N. (2004). Tourism Management. Australia: Pearson Education.

Porter, M.E. (1990). The competitive advantage of nations. New York: Free Press.

Ritchie, J.R.B., \& Crouch, G.I. (1993). Competitiveness in International Tourism: A Framework for Understanding and Analysis. Proceedings of the 43rd Congress of the Association Internationale d'Experts Scientifique du Tourisme, 17-23 October, San Carlos de Bariloche, Argentina (pp. 23-71).

Ritchie, J.R.B., \& Crouch, G.I. (2000). The Competitive Destination: A Sustainability Perspective. Tourism Management, 21(1), 1-7.

Ritchie, B., \& Crouch, G.I. (2003). The competitive destination: A sustainable tourism perspective. Wallingford: CABI Publishing.

UNWTO. (2016). International tourist arrivals up 4\% reach a record 1.2 billion in 2015. Retrieved April 6, 2016 from http://media.unwto.org/press-release/2016-01-18/ international-tourist-arrivals-4-reach-record12-billion-2015

World Economic Forum. (2015a). The Travel \& Tourism Competitiveness Report 2015. Geneva: World Economic Forum.

World Economic Forum. (2015b). The Global Competitiveness Report 2015-2016. Retrieved April 6, 2016 from http://www3.weforum.org/docs/gcr/2015-2016/Global_Competitiveness_Report_2015-2016.pdf

WTO. (2015). Azerbaijan. Retrieved April 6, 2016 from http://stat.wto.org/CountryProfiles/AZ_e.htm

WTO. (2015). Georgia. Retrieved April 6, 2016 from http://stat.wto.org/CountryProfile/WSDBCountryPFView.aspx? Language $=\mathrm{E} \&$ Country $=\mathrm{GE}$

WTTC. (2016). Travel \& Tourism Economic Impact Research 2016: Azerbaijan. Retrieved April 6, 2016 from http://www.wttc.org/-/media/files/reports/economic-impact-research/countries-2016/azerbaijan2016.pdf

WTTC. (2016). Travel \& Tourism Economic Impact Research 2016: Georgia. Retrieved April 6, 2016 from http://www.wttc.org/-/media/files/reports/economic-impact-research/countries-2016/georgia2016. pdf

WTTC. (2016). Travel \& Tourism Economic Impact Research 2016: World. Retrieved April 6, 2016 from http://www.wttc.org/-/media/files/reports/economicimpact-research/regions-2016/world2016.pdf 